\title{
Highlight report: spheroids from stem cell-derived hepatocyte-like cells
}

\author{
Patrick Nell ${ }^{1}$
}

Received: 7 November 2018 / Accepted: 8 November 2018 / Published online: 16 November 2018

c) Springer-Verlag GmbH Germany, part of Springer Nature 2018

In the August issue of the Archives of Toxicology Hassan Rashidi from the University of Edinburgh and colleagues published a study about 3D liver tissue-like spheroids generated from pluripotent stem cells (Rashidi et al. 2018). The authors used hPSC cell lines including the stem cell lines H9 and Man12, and the hiPSC lines FSPS13B and P106 (Cameron et al. 2015). Stem cells were differentiated via definitive endoderm to form hepatoblasts and were further differentiated to hepatocyte-like cells under the influence of HGF and OSM using culture conditions where the cells can form spheroids (Rashidi et al. 2018). Under these conditions, the spheroids could be maintained in culture for up to 1 year. The spheroids showed a high expression of HNF4A and albumin (Rashidi et al. 2018). Expression of hepatocyte markers, such as CYP3A4, SULT1 or MRP1, was seen in the periphery of the spheroids but not in the center. Importantly, similar results were obtained with hESC and hiPSC using the same protocol (Rashidi et al. 2018). Moreover, it was possible to transplant the spheroids intraperitoneally or subcutaneously into mice after partial hepatectomy as extrahepatic support system.

Currently, much research work is performed to establish hepatocyte in vitro systems for toxicity testing (Godoy et al. 2016; Hewitt et al. 2007; Leist et al. 2017; Deharde et al. 2016; Ghallab 2017; Stöber 2016; Hammad 2013). Besides their well-established use as metabolizing systems and for studies of enzyme induction, they are increasingly used for omics-based studies of test compounds (Parmentier et al. 2017; Vatakuti et al. 2017; Rodrigues et al. 2018; Grinberg et al. 2014; Arbo et al. 2016; Shinde et al. 2015). Often interpretation of in vivo studies of hepatotoxicity is supported by in vitro experiments and in silico methods (Schenk et al.

Patrick Nell

nell@ifado.de

1 IfADo-Leibniz Research Centre for Working Environment and Human Factors at TU Dortmund, Ardeystr. 67, 44139 Dortmund, Germany
2017; Ghallab et al. 2016; Jansen et al. 2017; Vartak et al. 2016; Stöber 2016; Sezgin et al. 2018). One of the perspectives of this branch of stem cell research is that it may lead to an unlimited supply of human hepatocytes (Hammad et al. 2014; Godoy et al. 2013, 2016; Gomez-Lechon and Tolosa 2016; Brulport et al. 2007). A further prospect is that iPS cells from humans with genetic, e.g., metabolic diseases may be used to generate adult cells of organs or tumor cells (Lee et al. 2018; Stewart et al. 2012). However, a limitation of current differentiation protocols is that the generated 'hepatocyte-like cells' (HLC) still show major differences compared to naturally developed or 'primary' human hepatocytes (Godoy et al. 2016, 2018). On the one side, numerous genes responsible for hepatocyte functions are expressed at much too low levels compared to primary hepatocytes. On the other side, HLC express genes representing, e.g., colon features that are not seen in real hepatocytes. Rashidi et al. are to be congratulated that their technique opens new perspectives for in vivo applications. A limitation is that the differentiation status of their HLCs has not been characterized by an unbiased method, e.g. genome-wide expression analysis, compared to primary human hepatocytes. Future, studies will have to show whether the supportive effect of HLC-spheroids in mouse models of partial hepatectomy have a clinical perspective.

\section{Compliance with ethical standards}

Conflict of interest The author declares that he has no conflict of interest.

\section{References}

Arbo MD, Melega S, Stöber R, de Lourdes Bastos M, Carmo H, Hengstler JG (2016) Hepatotoxicity of piperazine designer drugs: upregulation of key enzymes of cholesterol and lipid biosynthesis. Arch Toxicol 90(12):3045-3060 
Brulport M, Schormann W, Bauer A, Lupp A, Zulewski H, Hengstler JG (2007) Fate of extrahepatic human stem and precursor cells after transplantation into mouse livers. Hepatology 46(3):861-870

Cameron K, Tan R, Schmidt-Heck W, Godoy P, Forbes SJ, Hay DC (2015) Recombinant laminins drive the differentiation and selforganization of hESC-derived hepatocytes. Stem Cell Reports 5(6):1250-1262. https://doi.org/10.1016/j.stemcr.2015.10.016

Deharde D, Schneider C, Hiller T, Pratschke J, Zeilinger K, Damm G (2016) Bile canaliculi formation and biliary transport in 3D sandwich-cultured hepatocytes in dependence of the extracellular matrix composition. Arch Toxicol 90(10):2497-2511

Ghallab A (2017) Highlight report: metabolomics in hepatotoxicity testing. EXCLI J 16:1323-1325. https://doi.org/10.17179/excli 2017-1041 (eCollection 2017. No abstract available)

Ghallab A, Cellière G, Henkel SG, Drasdo D, Gebhardt R, Hengstler JG (2016) Model-guided identification of a therapeutic strategy to reduce hyperammonemia in liver diseases. J Hepatol 64(4):860 871. https://doi.org/10.1016/j.jhep.2015.11.018

Godoy P, Hewitt NJ, Albrecht U, Xu JJ, Yarborough KM, Hengstler JG (2013) Recent advances in 2D and 3D in vitro systems using primary hepatocytes, alternative hepatocyte sources and nonparenchymal liver cells and their use in investigating mechanisms of hepatotoxicity, cell signaling and ADME. Arch Toxicol 87(8):1315-1530

Godoy P, Widera A, Schmidt-Heck W, Blüthgen N, Dooley S, Hengstler JG (2016) Gene network activity in cultivated primary hepatocytes is highly similar to diseased mammalian liver tissue. Arch Toxicol 90(10):2513-2529

Godoy P, Schmidt-Heck W, Hellwig B, Walter J, Blüthgen N, Hengstler JG (2018) Assessment of stem cell differentiation based on genome-wide expression profiles. Philos Trans R Soc Lond B Biol Sci 5(1750):373. https://doi.org/10.1098/rstb.2017.0221 (Review)

Gómez-Lechón MJ, Tolosa L (2016) Human hepatocytes derived from pluripotent stem cells: a promising cell model for drug hepatotoxicity screening. Arch Toxicol 90(9):2049-2061. https://doi. org/10.1007/s00204-016-1756-1. (Review)

Grinberg M, Stöber RM, Edlund K, Leist M, Rahnenführer J, Hengstler JG (2014) Toxicogenomics directory of chemically exposed human hepatocytes. Arch Toxicol 88(12):2261-2287

Hammad S (2013) Advances in 2D and 3D in vitro systems for hepatotoxicity testing. EXCLI J 12:993-996. (eCollection 2013. No abstract available)

Hammad S, Hoehme S, Friebel A, Gebhardt R, Drasdo D, Hengstler JG (2014) Protocols for staining of bile canalicular and sinusoidal networks of human, mouse and pig livers, three-dimensional reconstruction and quantification of tissue microarchitecture by image processing and analysis. Arch Toxicol 88(5):1161-1183

Hewitt NJ, Lechón MJ, Houston JB, LeCluyse E, Groothuis GM, Hengstler JG (2007) Primary hepatocytes: current understanding of the regulation of metabolic enzymes and transporter proteins, and pharmaceutical practice for the use of hepatocytes in metabolism, enzyme induction, transporter, clearance, and hepatotoxicity studies. Drug Metab Rev 39(1):159-234 (Review)

Jansen PL, Ghallab A, Vartak N, Reif R, Schaap FG, Hampe J, Hengstler JG (2017) The ascending pathophysiology of cholestatic liver disease. Hepatology 65(2):722-738
Lee JH, Liu JW, Lin SZ, Harn HJ, Chiou TW (2018) Advances in patient-specific induced pluripotent stem cells shed light on drug discovery for amyotrophic lateral sclerosis. Cell Transplant 27(9):1301-1312. https://doi.org/10.1177/0963689718785154

Leist M, Ghallab A, Graepel R, Kroese D, van de Water B, Hengstler JG (2017) Adverse outcome pathways: opportunities, limitations and open questions. Arch Toxicol 91(11):3477-3505

Parmentier C, Couttet P, Wolf A, Zaccharias T, Heyd B, Bachellier P, Uteng M, Richert L (2017) Evaluation of transcriptomic signature as a valuable tool to study drug-induced cholestasis in primary human hepatocytes. Arch Toxicol 91(8):2879-2893. https://doi. org/10.1007/s00204-017-1930-0

Rashidi H, Luu NT, Alwahsh SM, Forbes SJ, Newsome PN, Hay DC (2018) In vitro systems 3D human liver tissue from pluripotent stem cells displays stable phenotype in vitro and supports compromised liver function in vivo. Arch Toxicol 92:3117-3129. https:// doi.org/10.1007/s00204-018-2280-2

Rodrigues RM, Kollipara L, Chaudhari U, Vanhaecke T, Rogiers V, Vinken M (2018) Omics-based responses induced by bosentan in human hepatoma HepaRG cell cultures. Arch Toxicol 92(6):1939-1952

Schenk A, Ghallab A, Hofmann U, Teutonico D, Hengstler JG, Kuepfer L (2017) Physiologically-based modelling in mice suggests an aggravated loss of clearance capacity after toxic liver damage. Sci Rep 7(1):6224

Sezgin S, Hassan R, Zühlke S, Kuepfer L, Hengstler JG, Spiteller M, Ghallab A (2018) Spatio-temporal visualization of the distribution of acetaminophen as well as its metabolites and adducts in mouse livers by MALDI MSI. Arch Toxicol 92(9):2963-2977

Shinde V, Stöber R, Nemade H, Sotiriadou I, Hescheler J, Hengstler J, Sachinidis A (2015) Transcriptomics of hepatocytes treated with toxicants for investigating molecular mechanisms underlying hepatotoxicity. Methods Mol Biol 1250:225-240. https://doi. org/10.1007/978-1-4939-2074-7_16

Stewart JD, Marchan R, Lesjak MS, Staude H, Steiner E, Hengstler JG (2012) Choline-releasing glycerophosphodiesterase EDI3 drives tumor cell migration and metastasis. Proc Natl Acad Sci USA 109(21):8155-8160. https://doi.org/10.1073/pnas.1117654109

Stöber R (2016) Pathophysiology of cholestatic liver disease and its relevance for in vitro tests of hepatotoxicity. EXCLI J 15:870-871. https://doi.org/10.17179/excli2016-864 (eCollection 2016. No abstract available)

Vartak N, Damle-Vartak A, Richter B, Dirsch O, Dahmen U, Hammad S, Hengstler JG (2016) Cholestasis-induced adaptive remodeling of interlobular bile ducts. Hepatology 63(3):951-964

Vatakuti S, Olinga P, Pennings JLA, Groothuis GMM (2017) Validation of precision-cut liver slices to study drug-induced cholestasis: a transcriptomics approach. Arch Toxicol 91(3):1401-1412. https ://doi.org/10.1007/s00204-016-1778-8

Vatakuti S, Olinga P, Pennings JLA, Groothuis GMM (2018) Validation of precision-cut liver slices to study drug-induced cholestasis: a transcriptomics approach. Arch Toxicol 91(3):1401-1412. https ://doi.org/10.1007/s00204-016-1778-8 